Thabiea : Journal of Natural Science Teaching
Program Studi Tadris Ilmu Pengetahuan Alam
Institut Agama Islam Negeri Kudus
$\begin{aligned} & \text { http://journal.stainkudus.ac.id/index.php/Thabiea } \\ & \text { p-issn: 2580-8974, e-issn: 2655-898x }\end{aligned}$

\title{
Respon Siswa Terhadap Alat Pirolisis Sampah Plastik Sebagai Media Pembelajaran Berbasis Lingkungan di SMP Musi Rawas
}

\author{
Wahyu Arini ${ }^{\mathrm{a}, 1^{*}}$, Endang Lovisia ${ }^{\mathrm{b}, 2}$ \\ a,bSTKIP-PGRI Lubuklinggau Jalan. Mayor Toha Kelurahan Taba Pingin Kota Lubuklinggau Kode Pos 31628 \\ ${ }^{1}$ wahyuarini02@gmail.com*; ${ }^{2}$ lovisiae@gmail.com
}

\begin{tabular}{ll}
\hline ABSTRAK \\
\hline Kata kunci: & Penelitian ini bertujuan untuk mengetahui respon siswa terhadap alat pirolisis \\
Media Pembelajaran; & sampah plastik sebagai media pembelajaran berbasis lingkungan di SMP Musi \\
Alat Pirolisis; & Rawas. Prosedur penelitian yang digunakan mengacu pada desain penelitian \\
Respon Siswa & pengembangan model ADDIE (Analisys, Design, Development, Implementation, \\
& Evaluation). Subjek penelitian adalah siswa kelas VII melalui teknik purposive \\
& sampling. Dalam penelitian ini, data hasil penelitian diperoleh dari lembar angket \\
& respon siswa dan guru serta hasil analisis data yang dilakukan untuk melihat dan \\
& mengamati permasalahan yang ada di SMP Negeri Kabupaten Musi Rawas dalam \\
& pembelajaran terkait sumber belajar berupa media belajar yang mereka gunakan \\
& dalam pembelajaran IPA bidang Fisika untuk materi suhu dan kalor. Berdasarkan \\
& hasil penelitian menunjukkan bahwa alat pirolisis tersebut sangat praktis dengan \\
& persentase uji coba kelompok luas sebesar 85,53\% dan uji coba kelompok terbatas \\
& $88,53 \%$. Respon pada buku panduan ketika uji coba kelompok luas dengan \\
persentase sebesar $86,79 \%$, serta respon pada buku panduan uji kelompok terbatas & menunjukkan level sangat praktis dengan persentase sebesar 88,5\%, sehingga dapat \\
& disimpilkan respon siswa cukup tinggi.
\end{tabular}

\begin{tabular}{|c|c|}
\hline & ABSTRACT \\
\hline $\begin{array}{l}\text { Key word: } \\
\text { Learning Media; } \\
\text { Pyrolysis Tool; } \\
\text { Student Response }\end{array}$ & $\begin{array}{l}\text { Student Responses to Plastic Waste Pyrolysis Tools as Environmental-Based } \\
\text { Learning Media in Musi Rawas Middle School. This study aims to determine } \\
\text { students' responses to the plastic waste pyrolysis tool as an environment-based } \\
\text { learning media in Musi Rawas Middle School. The research procedure used refers } \\
\text { to the design research development of the ADDIE model (Analysis, Design, } \\
\text { Development, Implementation, Evaluation). The subject of the research was Grade } \\
\text { VII students through purposive sampling technique. In this study, the research data } \\
\text { obtained from the questionnaire sheets of student and teacher responses and the } \\
\text { results of data analysis conducted to see and observe the problems that exist in the } \\
\text { State Junior High School of Musi Rawas in learning related learning resources in } \\
\text { the form of learning media that they use in science learning in the field of Physics } \\
\text { for temperature and heat material. Based on the results of the study showed that the } \\
\text { pyrolysis tool is very practical with the percentage of large group trials of } 85.53 \% \\
\text { and limited group trials of } 88.53 \% \text {. Response on the guidebooks on the large group } \\
\text { trials is } 86.79 \% \text {, as well as Response on the guidebooks on the limited group is } \\
\text { showed on very practical level with a percentage of } 88.5 \% \text {, so that it can be } \\
\text { summarized as high student responses. }\end{array}$ \\
\hline
\end{tabular}

Copyright $@ 2019$ Institut Agama Islam Negeri Kudus. All Right Reserved

\section{PENDAHULUAN}

Pendidikan memiliki peranan penting dalam kehidupan suatu bangsa. Perkembangan ilmu pengetahuan dan teknologi semakin mendorong upaya-upaya pembaruan dalam pemanfaatan hasil-hasil teknologi dalam proses 
belajar. Pemanfaatan ilmu dan teknologi dalam proses pembelajaran dapat membantu guru dalam menyampaikan materi ajar terlebih lagi dalam materi ajar fisika. Penggunaan media pengajaran dalam proses pengajaran sangat dianjurkan untuk mempertinggi kualitas pengajaran (Sudjana dan Rival, 2013). Pendidikan usaha sadar dan sistematis, yang dilakukan orang-orang yang diserahi tanggung jawab untuk mempengaruhi siswa agar mempunyai sifat dan tabiat sesuai dengan cita-cita pendidikan (Achmad dalam Muhson, 2010).

Fisika merupakan ilmu yang termasuk ke dalam rumpun IPA. Fisika mempelajari jawaban atas pertanyaan apa, mengapa dan bagaimana gejala alam yang berkaitan dengan komposisi, struktur, perubahan dan dinamika. Pengkonversian sampah plastik menjadi bahan bakar perlu diimplementasikan dalam pembelajaran fisika supaya dapat meningkatkan pemahaman siswa dalam menghadapi masalahmasalah lingkungan dengan pengembangan dan keterampilan proses dan sikap ilmiah dan bukan dengan cara menghafal konsep dan fakta-fakta. Dan Fisika merupakan ilmu pengetahuan yang digolongkan menjadi fakta, konsep, prinsip, hukum dan teori. Teori-teori yang dipelajari dalam ilmu fisika tidak hanya bersifat konkret, tetapi ada teori yang bersifat abstrak. Materi fisika yang teorinya bersifat abstrak sangat sulit untuk diajarkan ke peserta didik secara langsung. Fakta - fakta yang terdapat pada materi fisika juga tidak seluruhnya bisa secara nyata ditampilan oleh pendidik sehingga hal ini membuat peserta didik sulit dalam menguasai teori dan media pembelajaran yang diberikan oleh pendidik.

Media pembelajaran adalah alat ukur bantu yang digunakan oleh guru dalan proses pembelajaran. Menurut Sanjaya (2013) media bukan hanya berupa alat bantu atau bahan saja, akan tetapi hal-hal lain yang memungkinkan siswa dapat memperoleh pengetahuan. Anitah (2010) menyatakan bahwa media pembelajaran adalah setiap media yang di dalamnya terkandung informasi yang dapat dikomunikasikan kepada orang lain. Secara khusus media pembelajaran memiliki fungsi dan berperan dalam menangkap suatu objek atau peristiwa-peristiwa tertentu, memanipulasi keadaan, peristiwa, atau objek tertentu serta menambah gairah dan motivasi belajar siswa (Sanjaya, 2013). Media pembelajaran dapat meningkatkan hasil belajar siswa, khususnya materi yang digunakan di sekolah yaitu pembelajaran materi IPA.

Untuk menyesuaikan perkembangan tersebut menuntut kreatifitas dan kualitas sumber daya manusia harus ditingkatkan yang dapat dilakukan melalui jalur pendidikan dengan menggunakan media pembelajaran. Kreativitas seseorang diawali dari berfikir kreatif dalam mengeluarkan ide untuk menyelesaikan permasalahan (Fikri, Viki dan Paidi, 2018).

Maka dari itu untuk meningkatkan kualitas peserta didik melalui pengajaran IPA, guru diharapkan tidak hanya memahami disiplin ilmu IPA, tetapi hendaknya juga memahami hakikat proses pembelajaran IPA yang mencakup tiga ranah kemampuan, yaitu kognitif, afektif, dan psikomotor. Sehingga pengalaman belajar IPA harus memberikan pertumbuhan dan perkembangan siswa pada setiap aspek kemampuan tersebut. Produk pirolisis selain dopengaruhi oleh suhu dan waktu, juga oleh laju pemanasan, sehingga dapat dikembangkan sebagai sumber belajar berupa media pembelajaran IPA dalam memahami materi suhu dan kalor di SMP Kabupaten Musi Rawas.

Di Kabupaten Musi Rawas kompisis sampah yang paling banyak adalah plastik, sedangkan plastik tidak mengalami pengomposan atau tidak bisa terurai sehingga sampah plastik ini dapat merusak kelestarian lingkungan. Dalam hal ini, alat pirolisis sampah plastik sebagai media belajar berbasis lingkungan diharapkan dapat menjadi sumber belajar dan bisa membangun kesadaran siswa dalam mencintai lingkungan hidup dan menghasilkan produk yang bermanfaat serta dapat menarik minat, motivasi belajar siswa dan pemahaman siswa terhadap pelajaran sehingga respon siswa terhadap alat yang digunakan akan menjadi lebih baik.

Respon siswa adalah tanggapan dan reaksi siswa yang diberikan selama pembelajaran 
(Aisyah dkk, 2016). Respon siswa akan rendah jika siswa merasa kurang tertarik. Untuk mengetahui respon siswa, dapat menggunakan angket. Angket menurut Riduwan (2007) adalah daftar pertanyaan yang diberikan kepada subjek penelitian untuk memberikan respon sesuai dengan permintaan peneliti. Informasi yang diperoleh melalui angket dapat memberikan gambaran (deskripsi) tentang karakteristik dari individu atau sekelompok responden. Angket terdiri dari atas dua aspek, yaitu tanggapan dan reaksi. Pada aspek tanggapan terdiri atas dua indicator, yaitu format dan relevansi. Sementara aspek reaksi terdiri atas tiga indikator, yaitu keterkaitan, kepuasan dan percaya diri.

Respon merupakan suatu tingkah laku yang dipengaruhi karena adanya tanggapan dan rangsangan dari lingkungan. Respon siswa adalah tingkah laku atau reaksi siswa selama mengikuti kegiatan pembelajaran. Suatu respon bisa muncul apabila melibatkan panca indra dalam mengamati dan memperhatikan suatu obyek pengamatan. Terdapat beberapa faktor yang mempengaruhi adanya suatu respon, yakni pengalaman, proses belajar, dan nilai kepribadian.

Menurut Amir (2015), respon dibedakan menjadi tiga bagian yaitu kognitif, afektif dan konatif. Respon muncul apabila ada objek yang diamati, ada perhatian terhadap suatu objek pengamatan dan adanya panca indera sebagai penangkap objek yang diamati, selain itu dalam pemunculannya respon ada beberapa faktor yang mempengaruhi yaitu pengalaman, proses kerja, proses belajar, tingkat pengalaman individu, dan nilai kepribadiannya. Dari uraian di atas menunjukan bahwa respon dapat berupa persyaratan dalam bentuk pendapat yang dianggap baik memenuhi syarat secara rasional dapat dikemukakan sehingga dapat disimpulkan bahwa respon adalah kesan atau reaksi setelah kita mengamati aktifitas mengindra, menilai, objek terbentuknya sikap terhadap objek tersebut dapat berupa sikap negatif atau postif (Hidayati dan Muhammad, 2013). Maka dari itu perlunya sumber-sumber pembelajaran yang dapat membantu dan mendorong siswa untuk memahami materi fisika yang termasuk dalam mata pelajaran IPA yang akan dipelajari khususnya di SMP.

Guru dapat melihat dan menilai konsep ataupun metode yang digunakan dalam kegiatan belajar dan mengajar dengan cara mengamati respon yang ditunjukkan oleh siswa, sehingga respon memiliki peranan penting dalam kegiatan belajar mengajar. Pembelajaran yang menarik membuat siswa lebih senang dan mudah menyerap ilmu yang terlihat dari respon siswa selama proses pembelajaran. Respon berarti sebuah reaksi atau tanggapan berupa penerimaan, penolakan, atau sikap acuh tak acuh terhadap apa yang disampaikan oleh komunikator dalam pesannya.

Pada hakikatnya proses pembelajaran merupakan proses komunikasi atau penyampaian pesan dari pengantar ke penerima. Pesan berupa materi pelajaran yang dituangkan ke dalam simbol-simbol komunikasi baik verbal (kata-kata dan tulisan) maupun nonverbal. Pesan inilah yang akan ditangkap oleh siswa sebagai pengetahuan.

Dalam hal ini respon siswa dapat menjadi satu kebiasaan dengan beberapa urutan tertentu yaitu penyajian rangsangan, pandangan dari manusia akan rangsangan, interprestasi dari rangsangan, menanggapi rangsangan, pandangan akibat menganggapi rangsangan, interpretasi akan akibat dan membuat tanggapan lebih lanjut serta membangun hubungan rangsanganrangsangan yang mantap. Untuk melihat suatu proses pembelajaran dalam kegiatan proses belajar mengajar yang juga berperan dalam menentukan keberhasilan belajar siswa. Dari proses pembelajaran itu akan terjadi sebuah kegiatan yang timbul baik antara guru dengan siswa untuk menuju tujuan yang lebih baik. Oleh karena itu, proses pembelajaran yang tepat sangat dibutuhkan dalam kegiatan belajar mengajar untuk menghasilkan pemahaman yang baik bagi siswa. Untuk melakukan sebuah proses pembelajaran terlebih dahulu harus memahami kata pembelajaran serta media pembelajaran.

Keberhasilan pembelajaran sangat ditentukan oleh dua komponen utama yaitu metode mengajar dan media pembelajaran. Kedua komponen ini saling berkaitan dan tidak 
bisa dipisahkan. Penggunaan dan pemilihan salah satu metode mengajar tertentu mempunyai konsekuensi pada penggunaan jenis media pembelajaran yang sesuai. Fungsi media dalam proses belajar mengajar yaitu untuk meningkatkan rangsangan peserta didik dalam kegiatan minat belajar.

Media apabila dipahami secara garis besar adalah manusia, materi atau kejadian yang membangun kondisi yang membuat siswa mampu memperoleh pengetahuan, keterampilan atau sikap, dalam pengertian ini guru, buku teks, dan lingkungan sekolah merupakan media. Secara lebih khusus, pengertian media dalam proses belajar mengajar cenderung diartikan sevagai alat-alat grafis, photografis atau elektronis untuk menangkap, memproses, dan menyusun kembali informasi visual atau verbal.

Media merupakan salah satu komponen yang memiliki peran penting untuk menjembatani penyampaian materi dalam proses pembelajaran. Tegeh (dalam Pirgayanti, 2015) media adalah segala sesuatu yang dapat digunakan untuk menyalurkan pesan dari pengirim pesan ke penerima pesan sehingga dapat merangsang pikiran, perasaan, perhatian, dan minat serta perhatian siswa sedemikian rupa, sehingga proses belajar dapat terjadi.

Menurut Sumantri (dalam Adam, 2015) menjelaskan bahwa media pembelajaran merupakan segala alat fisik yang dapat menyajikan pesan serta perangsang peserta didik untuk belajar, contoh buku, film, kaset. Sedangkan menurut Nasution(dalam Adam, 2015) menuliskan media pembelajaran menurut (1) Gagne bahwa media pembelajaran sebagai komponen sumber belajar di lingkungan siswa yang dapat merangsang siswa untuk belajar, (2) Briggs media pembelajaran adalah wahana fisik yang mengandung materi pelajaran dan (3) Schramm media pembelajaran adalah teknik pembawa informasi atau pesan pembelajaran.

Rudi (dalam Hafid, 2011) menyatakan bahwa manfaat media dalam pembelajaran dapat memperoleh pengetahuan siswa yang digambarkan oleh kerucut pengalaman Edgar Dale bahwa pengetahuan akan semakin abstrak pesan hanya disampaikan melalui kata verbal.
Secara umum media mempunyai manfaat yaitu: memperjelas pesan agar tidak terlalu verbalistis, mengatasi keterbatasan ruang, waktu, tenaga dan daya indera, menimbulkan gairah belajar, interaksi lebih langsung antara siwa dengan sumber belajar, memungkinkan anak belajar mandiri sesuai dengan bakat dan kemampuan visual, ouditori dan kinestiknya, memberi rangsangan yang sama, mempersamakan pengalaman, menimbulkan persepsi yang sama, mengadirkan objek-objek yang terlalu berbahaya atau sukar didapat ke dalam lingkungan belajar dan menampilkan objek yang terlalu besar.

Penggunaan media dalam pembelajaran didasarkan pada konsep bahwa belajar dapat ditempuh melalui berbagai cara, antara lain dengan mengalami secara langsung, dengan mengamati orang lain, dan dengan membaca serta mendengar. Olsen (dalam Maimunah, 2016) mengungkapkan bahwa prosedur belajar dapat ditempuh dalam tiga tahap, yaitu pembelajaran langsung melalui pengalaman langsung, pembelajaran tidak langsung dapat melalui alat peraga atau media pembelajaran, pembelajaran tidak langsung melalui lambing kata. Kedudukan media dalam komponen pembelajaran sangat penting bahkan sejajar dengan metode pembelajaran, karena metode yang digunakan dalam proses pembelajaran biasnaya akan menurut media apa yang digunakan dapat diitergrasikan dan diadaptasikan dengan kondisi yang dihadapi. Maka kedudukan media dalam suatu pembelajaran sangatlah penting dan menentukan.

Dalam kaitannya pemanfaatan sumber belajar dalam pembelajaran terdapat beberapa factor yang dapat mempengaruhi usaha dalam pemanfaatanya yaitu kemauan tenaga pengajar, kemampuan tenaga pengajar untuk dapat melihat alam sekitar yang dapat digunakan untuk pengajaran, kemampuan tenaga pengajar untuk dapat menggunakan sumber alam sekitar dalam pembelajaran (Supriadi, 2015). Maka degan demikian bahwa peranan sumber belajar erat sekali hubungannya dengan pola pembelajaran yang dilakukan. Pada kegiatan pembelajaran individual, fokusnya adalah peserta diidk, sedang 
bagi tenaga pengajar memiliki peranan yang sama dengan sumber belajar lainnya.

Perkembangan sumber belajar untuk mata pelajaran IPA dalam memahami materi fisika di SMP Kabupaten Musi Rawas masih sangat sedikit dan kurang variatif. Padahal saat ini dengan adanya kurikulum 2013 siswa dituntut untuk belajar secara mandiri. Sebagai bentuk usaha untuk mengoptimalkan pembelajaran IPA di SMP, maka penelitian mengenai respon siswa terhadap media pembelajaran alat pirolisis sampah plastik berbasis lingkungan ini perlu dibuat dan dikembangkan sebagai sumber belajar berbentuk alat peraga yang secara real dapat digunakan serta mempermudah siswa dalam memahami dan mempelajari materi suhu dan kalor, selain itu siswa juga dapat memabantu program pemerintahan setempat dalam meminimalisir jumlah sampah plastik yang ada di lingkungan.

Berdasarkan penelitian terdahulu menunjukkan pembelajaran menggunakan amedia pembelajaran alat priolisis menjadi daya pendukung siswa dalam memahami materi di kelas. Dalam hal ini peneliti berusaha membuat media pembelajaran alat priolisis mengenai respon siswa berbasis lingkungan maka peneliti bermaksud melakukan penelitian dengan judul "Respon Siswa Terhadap Media Pembelajaran Alat Pirolisis Sampah Plastik Berbasis Lingkungan Di SMP Kabupaten Musi Rawas".

\section{METODE}

a. Jenis dan Rancangan Penelitian

Pengembangan media belajar ini menggunakan jenis penelitian pengembangan (research and development). Metode penelitian dan pengembangan adalah metode penelitian yang digunakan untuk menghasilkan produk tertentu dan menguji keefektifan produk tersebut. Penelitian jenis ini berbeda dengan penelitian pendidikan lainnya karena tujuannya adalah mengembangkan produk berdasarkan uji coba untuk kemudian direvisi sampai menghasilkan produk yang layak pakai. Borg and Gall (Sugiono, 2011) menyatakan bahwa penelitian pengembangan adalah suatu proses yang digunakan untuk mengembangkan dan memvalidasi produk-produk yang digunakan dalam pendidikan dan pembelajaran.

Penelitian ini dilaksanakan di sekolah SMP Kabupaten Musi Rawas yang berkategori tinggi, sedang, dan rendah yang tersebar di lingkungan Dinas Pendidikan Kabupaten Musi Rawas. Dengan alasan memilih sekolah tersebut untuk mewakili seluruh jumlah sekolah tingkat SMA yang ada di Musi Rawas. Dalam penelitian ini yang menjadi subjek penelitian pada saat identifikasi kelayakan media belajar adalah siswa kelas VII melalui teknik purposive sampling.

Data yang digunakan dalam penelitian pengembangan ini adalah data kualitatif dan kuantitatif, data kualitatif berupa masukan, koreksi dan kritik yang diberikan oleh dosen ahli meteri, dosen ahli media dan guru fisika terhadap media belajar. Data kuantitatif adalah data hasil penelitian yang diperoleh dari lembar penelitian angket respon siswa, dan hasil belajar siswa berupa pretest dan posttest. Tahap analisis dalam penelitian ini dilakukan untuk melihat dan mengamati permasalahan yang ada di SMP Kabupaten Musi Rawas dalam pembelajaran terkait sumber belajar berupa media belajar yang mereka gunakan dalam pembelajaran IPA bidang Fisika untuk materi suhu dan kalor. Karena diketahui selama ini materi suhu dan kalor lebih banyak menggunakan media belajar yang biasa atau sedrhana dan kurang berkaitan dengan lingkungan yang bisa dimanfaatkan untuk sumber kegiatan belajar siswa, sehingga siswa kurang termotivasi dan kurang aktif dalam belajar. Kemudian pada tahap desain penelitian melakukan kegiatan merancang media belajar berupa alat pirolisis sampah plastik yang dapat digunakan untuk memahami materi suhu dan kalor serta memanfaatkan lingkungan sekitar sebagai acuan dalam proses pembelajaran.

Setelah diproses rancangan alat pirolisis sampah plastik sebagai media belajar, kemudian dilanjutkan dengan tahap pengembangan alat meliputi tahap pembuatan 
atau penyusunan alat pirolisis sampah plastik sesuai dengan desain yang telah direncanakan. Data kelayakan alat pirolisis ini diperoleh dengan cara memberikan angket kepada ahli materi dan ahli media (dosen dan guru fisika), angket tersebut dapat berupa lembar penilaian yang terdiri dari aspek isi buku penggunaan alat terhadap materi suhu dan kalor, penyajian, kemanfaatan dan pengoperasian dengan tujuan alat pirolisis yang selanjutnya akan direvisi sesuai dengan masukan dari para ahli.

Dalam tahap implementasi, setelah produk melalui proses pengembangan dan revisi dari para ahli maka alat pirolisis siap untuk di implementasikan kepada siswa di SMP Kabupaten Musi Rawas. Peneliti menggunakan media belajar berupa alat pirolisis dalam pembelajaran pada materi suhu dan kalor, setelah menggunakan alat pirolisis dalam mempelajari materi suhu dan kalor, mengisi angket respon, kemudian siswa juga diminta untuk memberi tanggapan atau saran terhadap media belajar tersebut.

Selanjutnya penelitian masuk dalam tahap evaluasi, evaluasi adalah proses untuk melihat apakah media pembelajaran yang dikembangkan telah berhasil dan layak digunakan sebagai media pembelajaran atau tidak (Benny, 2009). Pada tahap ini dilakukan proses untuk menganalisis hasil implementasi sebagai bahan perbaikan media belajar. Masukan dari siswa kemudian dianalisis dan dilakukan revisi kembali pada bagian-bagian alat pirolisis yang belum sesuai. Sehingga setelah revisi, produk yang dihasilkan sebagai media belajar dapat digunakan dan layak sebagai media pembelajaran.

Dalam penelitian ini, prosedur yang digunakan mengacu pada desain pengembangan model ADDIE (Analisys, Design, Development, Implementation, Evaluation). Pemilihan model pengembangan ini didasarkan pada alasan bahwa tahapan-tahapan dasar desain pengembangan ADDIE sederhana, mudah dipelajari, simpel serta lebih mudah dipraktikkan dalam pengembangan media pembelajaran.

b. Teknik Analisis Data

Data yang digunakan dalam penelitian pengembangan ini adalah data kualitatif dan kuantitatif, data kualitatif berupa masukan, koreksi dan kritik yang diberikan oleh dosen ahli meteri, dosen ahli media dan guru fisika terhadap media belajar. Data kuantitatif adalah data hasil penelitian yang diperoleh dari lembar penelitian angket respon siswa dan guru. Tahap analisis dalam penelitian ini dilakukan untuk melihat dan mengamati permasalahan yang ada di SMP Kabupaten Musi Rawas dalam pembelajaran terkait sumber belajar berupa media belajar yang mereka gunakan dalam pembelajaran IPA bidang Fisika untuk materi suhu dan kalor. Karena diketahui selama ini materi suhu dan kalor lebih banyak menggunakan media belajar yang biasa atau sedrhana dan kurang berkaitan dengan lingkungan yang bisa dimanfaatkan untuk sumber kegiatan belajar siswa, sehingga siswa kurang termotivasi dan kurang aktif dalam belajar.

Teknik pengumpulan data pada penelitian ini yaitu validasi ahli dan angket. Dengan instrument yang digunakan adalah yaitu lembar validasi ahli dan angket siswa. Analisis data dilakukan dengan teknik:

1. Analisis Validasi

Hasil alidasi dianalisis para ahli dengan cara deskriptif sebagai masukan untuk merevisi pembuatan media pembelajaran. Masukan tersebut ditulis pada lembar validasi. Setiap indikator penilaian yang terdapat pada lembar validasi ditampilkan dalam bentuk skala likert seperti terlihat pada Tabel 1 berikut:

Tabel 1. Kategori Nilai Lembar Validasi

\begin{tabular}{cc}
\hline Kategori Jawaban & $\begin{array}{c}\text { Skor } \\
\text { Penyataan }\end{array}$ \\
\hline Sangat Valid & 4 \\
Valid & 3 \\
Tidak Valid & 2 \\
Sangat Tidak Valid & 1 \\
\hline
\end{tabular}


Hasil validasi dari validator disajikan dalam bentuk tabel. Selanjutnya dicari Hasil Validasi ahli tersebut dengan menggunakan rumus :

$$
P=\frac{V_{i}}{n} \times 100 \%
$$

Keterangan:

$\mathrm{P}=$ Persentase penilaian dari validator

$V_{i}=$ Skor hasil penilaian validator $\mathrm{ke}-\mathrm{i}$

$n=$ Nilai skor maksimum ke-i

Selanjutnya persentase hasil validasi ahli yang didapatkan disesuaikan dengan kategori seperti yang terlihat pada Tabel dibawah ini berikut ini.

Tabel 2. Kategori Hasil Validasi Ahli Materi Alat

\begin{tabular}{cc}
\hline Persentase & Kriteria \\
\hline $\mathrm{P} \leq 100 \%$ & Sangat Baik \\
$65 \% \leq \mathrm{P}<80 \%$ & Baik \\
$45 \% \leq \mathrm{P}<60 \%$ & Kurang \\
$25 \% \leq \mathrm{P}<40 \%$ & Sangat Kurang \\
\hline
\end{tabular}

Tabel 3. Kategori Hasil Validasi Ahli Materi Buku Panduan

\begin{tabular}{cc}
\hline Persentase & Kriteria \\
\hline $\mathrm{P} \leq 100 \%$ & Sangat Baik \\
$65 \% \leq \mathrm{P}<82,5 \%$ & Baik \\
$45 \% \leq \mathrm{P}<62,5 \%$ & Kurang \\
$25 \% \leq \mathrm{P}<42,5 \%$ & Sangat Kurang \\
\hline
\end{tabular}

Tabel 4. Kategori Hasil Validasi Ahli Media Alat

\begin{tabular}{cc}
\hline Persentase & Kriteria \\
\hline $\mathrm{P} \leq 100 \%$ & Sangat Baik \\
$61,36 \% \leq \mathrm{P}<77,27 \%$ & Baik \\
$43,18 \% \leq \mathrm{P}<59,09 \%$ & Kurang \\
$25 \% \leq \mathrm{P}<40,91 \%$ & Sangat Kurang \\
\hline
\end{tabular}

Tabel 5. Kategori Hasil Validasi Ahli Media Buku Panduan

\begin{tabular}{cc}
\hline Persentase & Kriteria \\
\hline $\mathrm{P} \leq 100 \%$ & Sangat Baik \\
$62,5 \% \leq \mathrm{P}<78,13 \%$ & Baik \\
$43,75 \% \leq \mathrm{P}<59,38 \%$ & Kurang \\
$25 \% \leq \mathrm{P}<40,63 \%$ & Sangat Kurang \\
\hline
\end{tabular}

\section{Analisis Data Angket}

Angket yang diberikan kepada siswa dalam bentuk skala likert. Data yang diperoleh dianalisis untuk mendapatkan kepraktisan media pembelajaran alat pirolisis berbasis lingkungan. Data yang diperoleh melalui angket dianalisa dengan menerapkan skala likert untuk mengukur pendapat, persepsi pada penggunaan media. Data hasil angket disajikan dalam bentuk tabel dibawah berikut ini.

Tabel 6. Kategori Nilai Lembar Validasi

\begin{tabular}{cc}
\hline Kategori Jawaban & $\begin{array}{c}\text { Skor } \\
\text { Penyataan }\end{array}$ \\
\hline Sangat Setuju & 4 \\
Setuju & 3 \\
Tidak Setuju & 2 \\
Sangat Tidak Setuju & 1 \\
\hline
\end{tabular}

Hasil angket dari siswa disajikan dalam bentuk tabel. Selanjutnya dicari Hasil angket tersebut dengan menggunakan rumus :

$$
P=\frac{f_{i}}{n} \times 100 \%
$$

Keterangan:

$\mathrm{P}=$ Persentase kepraktisan

$f_{i}=$ Jumlah skor

$n=$ Nilai skor maksimum ke-i

Selanjutnya persentase hasil angket respon siswa yang didapatkan disesuaikan dengan kategori seperti yang terlihat pada Tabel dibawah ini berikut ini.

Tabel 7. Kategori Nilai Angket terhadap Alat Uji Terbatas

\begin{tabular}{cc}
\hline Persentase & Kriteria \\
\hline $82,14 \% \leq \mathrm{P} \leq 100 \%$ & Sangat Baik \\
$62,5 \% \leq \mathrm{P}<80,36 \%$ & Baik \\
$42,86 \% \leq \mathrm{P}<60,71 \%$ & Kurang \\
$21,42 \% \leq \mathrm{P}<40,07 \%$ & Sangat Kurang \\
\hline
\end{tabular}

Tabel 8. Kategori Nilai Angket terhadap Buku Panduan Uji Terbatas

\begin{tabular}{cc}
\hline Persentase & Kriteria \\
\hline $82, \% \leq \mathrm{P} \leq 100 \%$ & Sangat Baik \\
$62,5 \% \leq \mathrm{P}<80 \%$ & Baik \\
$42,5 \% \leq \mathrm{P}<60 \%$ & Kurang \\
$22,5 \% \leq \mathrm{P}<40, \%$ & Sangat Kurang \\
\hline
\end{tabular}

Tabel 9. Kategori Nilai Angket terhadap Alat Uji Luas

\begin{tabular}{cc}
\hline Persentase & Kriteria \\
\hline $78,13 \% \leq \mathrm{P} \leq 100 \%$ & Sangat Baik \\
$53,13 \% \leq \mathrm{P}<75 \%$ & Baik \\
$28,13 \% \leq \mathrm{P}<50 \%$ & Kurang \\
$0 \% \leq \mathrm{P}<25 \%$ & Sangat Kurang \\
\hline
\end{tabular}


Tabel 10. Kategori Nilai Angket terhadap Buku Panduan Uji Luas

\begin{tabular}{cc}
\hline Persentase & Kriteria \\
\hline $78,57 \% \leq \mathrm{P} \leq 100 \%$ & Sangat Baik \\
$53,57 \% \leq \mathrm{P}<75 \%$ & Baik \\
$28,57 \% \leq \mathrm{P}<50 \%$ & Kurang \\
$0 \% \leq \mathrm{P}<25 \%$ & Sangat Kurang \\
\hline
\end{tabular}

\section{HASIL DAN PEMBAHASAN}

Hasil penelitian dengan menerapkan media pembelajaran alat pirolisis berbasis lingkungan pada materi suhu dan kalor secara keseluruhan dilihat dari hasil respon guru dan siswa ketika menerapkan media pembelajaran tersebut dengan terlaksananya pembelajaran yang menyenangkan. Dalam hal ini penelitian bertujuan untuk mengetahui respon siswa terhadap media pembelajaran alat pirolisis berbasis lingkungan di SMP Kabupaten Musi Rawas. Pengembangan alat pirolisis terhadap sampah plastik ini untuk melihat kinerja hasil respon siswa terlihat dari antusias siswa selama melakukan kegiatan dengan menggunakan media pembelajaran alat pirolisis berbasis lingkungan.

Menurut Sudijono (2013) angket (questionnaire) juga dapat diartikan sebagai alat bantu dalam rangka penilaian hasil belajar. Kuesioner sering digunakan untuk menilai hasil belajar ranah afektif. Ia dapat berupa kuesioner bentuk pilihan ganda dan dapat pula berbentuk skala sikap. Skala yang mengukur sikap, sangat terkenal dan sering digunakan untuk mengungkap sikap peserta didik adalah skala likert. Angket respon siswa adalah instrument yang digunakan untuk mengukur tanggapan siswa terhadap pembelajaran. Secara data, respon siswa terhadap media pembelajaran alat pirolisis yang ditinjau dari 4 skala aspek penilaian yang menggunakan angket yaitu sangat praktis, praktis, kurang praktis, tidak praktis. Angket respon yang digunakan angket respon siswa, guru serta buku panduan, angket uji kelompok terbatas dan angket uji kelompok luas dengan menggunakan skala likert tipe 4 .

Pengembangan alat pirolisis terhadap sampah plastik ini untuk melihat kinerja hasil respon siswa. Dari lembar validasi yang telah diisi oleh validator diperoleh bahwa alat pirolisis tersebut tingkat valid nya sangat baik untuk ahli materi maupun media nya. Dengan persentase masing-masing $90 \%$ untuk materi dan $88,64 \%$ untuk media. Sedangkan untuk buku panduannya ahli materi sebesar $87,5 \%$ dan ahli media sebesar $84,37 \%$. Adapun persentase kevalidan alat pirolisis dapat dilihat pada gambar 7 berikut ini.

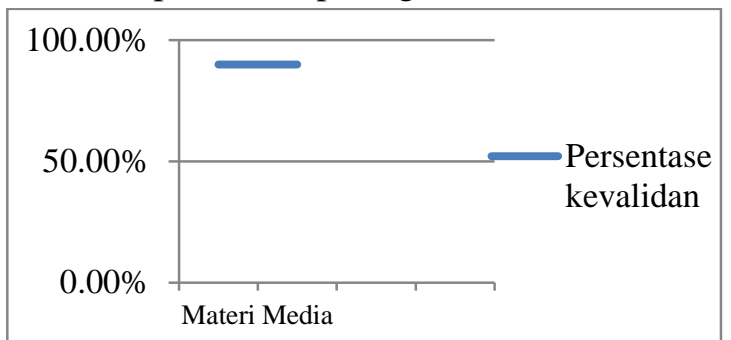

Gambar 1. Persentase Kevalidan Alat Pirolisis

Adapun persentase kevalidan buku panduan dapat dilihat pada gambar 2 berikut:

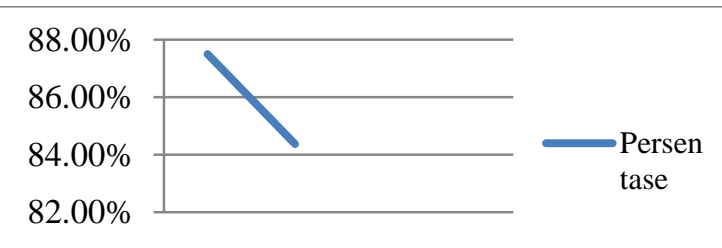

Gambar 2. Persentase Kevalidan Buku Panduan

Dari angket respon uji kelompok luas yang telah diisi oleh 27 siswa didapat bahwa alat pirolisis tersebut sangat praktis dengan persentase sebesar $89,87 \%$. Serta untuk buku panduannya menyatakan bahwa buku panduannya sangat praktis dengan persentase 90,07\%. Adapun persentase kepraktisan alat pirolisis dan buku panduan dapat dilihat pada gambar 3 di bawah ini.

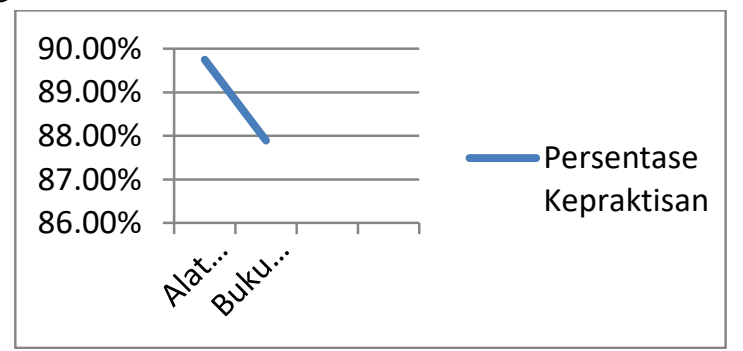

Gambar 3. Persentase Kepraktisan Alat Pirolisis dan Buku Panduan

Sedangkan hasil dari angket respon uji kelompok terbatas yang telah diisi oleh 9 siswa didapat bahwa alat pirolisis tersebut memenuhi kategori sangat baik. Adapun persentase respon 
siswa dan buku panduan dapat dilihat pada gambar 4 dan 5 di bawah ini.

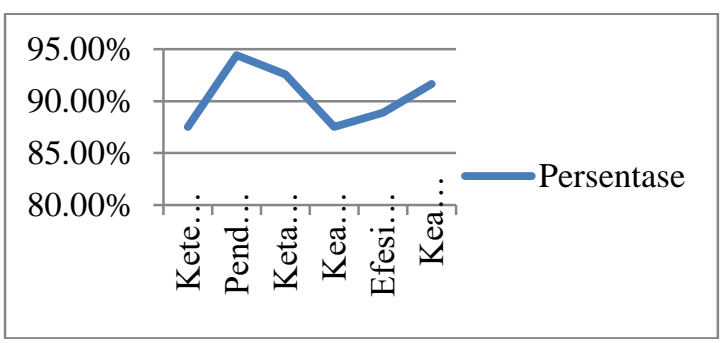

Gambar 4. Persentase Respon Siswa Uji Terbatas

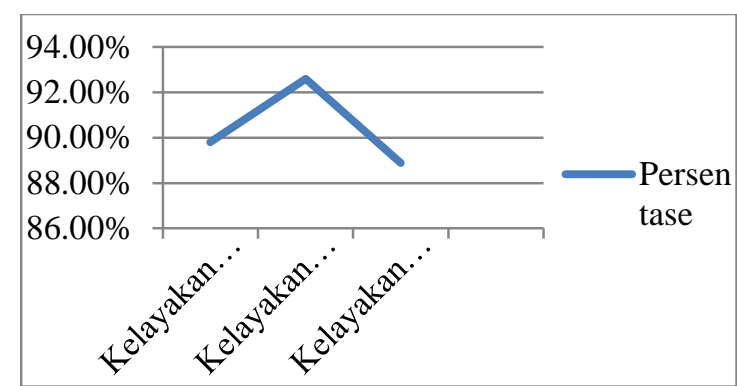

Gambar 5. Persentase Respon Siswa Uji Terbatas Terhadap Buku Panduan

\section{Kesimpulan}

Berdasarkan penelitian yang telah dilakukan tentang respon siswa terhadap alat pirolisis sampah plastic sebagai media pembelajaran berbasis lingkungan di SMP Kabupaten Musi Rawas , maka peneliti menyimpulkan bahwa: Respon siswa terhadap alat pirolisis sampah plastik sebagai media pembelajaran berbasis lingkungan di SMP Kabupaten Musi Rawas menunjukkan bahwa alat pirolisis tersebut sangat praktis dengan persentase sebesar $89,87 \%$.

\section{Referensi}

Aisyah, Panjaitan, R.G.P dkk,. 2016. Respon Siswa Terhadap Media E-Comic Bilingual Sub Materi Bagian-Bagian Darah. Jurnal Pendidikan dan Pembelajaran. 5 (3): 1-12.

Ali, Muhson. 2010. Pengembangan Media Pembelajaran Berbasis Teknologi Informasi. Jurnal Pendidikan Akuntansi Indonesia, 8(2) 1-10.

Amir, M.T. 2015. Merancang Kuesioner. Prenadamedia Group. Jakarta.

Anitah, S. 2010. Media Pembelajaran. LPP UNS dan UNS Press. Surakarta.
A.Pribadi, Benny. 2009. Model Desain Sistem Pembelajaran. Jakarta: PT Dian Rakyat.

Fikri., A.A., Ismah, V., \& Paidi, P. 2019. Pengembangan perangkat pembelajaran model Guided Inquiry untuk meningkatkan creative thinking Siswa. Thabiea: Journal of Natural Science Teaching. Vol (1)(01): 1-8.

Hafid. 2011. Sumber dan Media Pembelajaran. Jurnal Pendidikan Agama Islam, 6(2) 69-78.

Hidayati, N., dkk. 2013. Respon Guru dan Siswa terhadap Pembelajaran Permainan Bolavoli yang Dilakukan dengan Pendekatan Modifikasi (Pada Siswa Kelas V SDN Wateswinagun I Lamongan). Jurnal Pendidikan Olahraga dan Kesehatan. 1 (1): 104106.

Maimunah. 2016. Metode Penggunaan Media Pembelajaran. Jurnal Al-Afkar, 5(1)324.

Ni Kadek, Pirgayanti. 2015. Pengembangan Multimedia Pembelajaran Interaktif dengan Model Luther dalam Mata Pelajaran IPS pada Siswa Kelas VIII Semester Genap Tahun Pelajaran 2013/2014 di SMP Negeri 5 negara. Jurnal EDUTECH Undiksha, 3(1).

Riduwan. 2007. Skala Pengukuran VariabelVariabel Penelitian. Alfabeta. Bandung.

Sanjaya, W. 2013. Perencanaan dan Desain Sistem Pembelajaran. Alfabeta. Bandung.

Steffi, Adam, dkk. 2015. Pemanfaatan Media Pembelajaran Berbasis Teknologi Informasi Bagi Siswa Kelas X SMA Ananda Batam. Jurnal CBIS, 3(2) 7890.

Sudjana, N. dan Rivai, A. 2013. Media Pengajaran. Sinar Baru Algensindo. Bandung.

Sugiono. 2011. Metode Penelitian Kuantitatif, Kalitatif dan R\&D. Bandung: Alfabeta. 
Supriadi. 2015. Pemanfaatan Sumber Belajar

Lantanida Jorunal, 3(2).

dalam Proses Pembelajaran. 